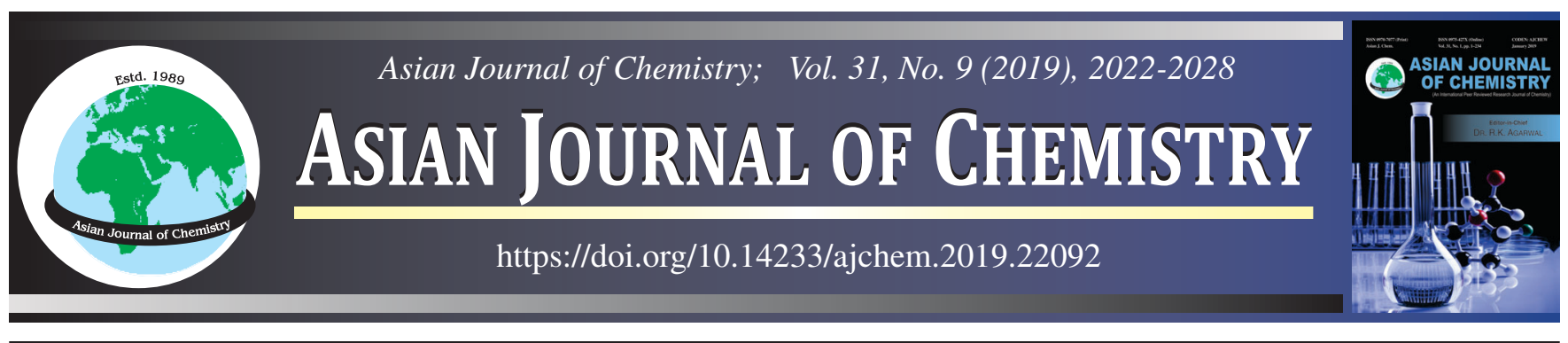

\title{
Synthesis and Characterization of Cobalt(III) Complex of 1,5-bis(2-Hydroxybenzamido)-3-aza pentane and its Interaction with Glutathione: A Kinetic and Spectrophotometric Study
}

Aravind Rudrarapu ${ }^{1}$, Gouri SankHar Brahma ${ }^{1, *}$ and SupraVa NayaK ${ }^{2}$

${ }^{1}$ Department of Chemistry, Faculty of Science and Technology, The ICFAI Foundation for Higher Education, Hyderabad-501203, India

${ }^{2}$ Department of Chemistry, Government College, Sundergarh-770002, India

*Corresponding author: E-mail: gsb_ad@ifheindia.org

Received: 22 March 2019;

Accepted: 22 April 2019;

Published online: 31 July 2019;

AJC-19492

\begin{abstract}
A new octahedral cobalt(III) complex of 1,5-bis(2-hydroxybenzamido)-3-aza pentane was synthesized and characterized by elemental analysis, UV-visible, IR, mass spectrometry and thermal analysis methods. Oxidative behaviour of the complex towards the physiologically abundant tripeptide, glutathione(GSH) was studied by UV-visible and FT-NMR techniques. Kinetics of electron transfer between the complex and GSH was studied at $25.0 \leq \mathrm{t} /{ }^{\circ} \mathrm{C} \leq 45.0,0.025 \leq\left[\mathrm{H}^{+}\right] / \mathrm{mol} \mathrm{dm}^{-3} \leq 0.20$ and $\mathrm{I}=1.0 \mathrm{~mol} \mathrm{dm}^{-3}\left(\mathrm{NaClO}_{4}\right)$. NMR spectra of the reaction mixture were taken as a function of time. Changes observed in the NMR-spectrum during the period of scanning are the initial disappearance of the fine structure and subsequent broadening of the signals of GSH protons. Peaks at ( $\delta$, ppm): 2.93 and 2.98, characteristics of $\mathrm{Cys}-\mathrm{CH}_{2} \delta$ protons in GSH get disappear slowly and new peaks develop at $(\delta, \mathrm{ppm}): 3.33$ and 3.38, corresponding to resonating frequencies of Cys- $\mathrm{CH}_{2} \delta$ protons in GSSG. Likewise, the peak at $(\delta, \mathrm{ppm}): 2.93$, characteristic of Cys- $\mathrm{CH}_{2} \delta$ proton in $\mathrm{GSH}$ is replaced by the resurgence of two peaks at $(\delta, \mathrm{ppm}): 4.3$ and $4.1 \mathrm{ppm}$, commensurate with the resonating frequencies of same set of protons as that of GSH but in a dimeric environment. The time dependent NMR simulation of the reaction reveals that GSH reduces the Co ${ }^{\text {III }}$ moiety successfully, while it gets converted into the dimer, GSSG. The relatively fast transformation of GSH to GSSG as evident from both electronic spectra and NMR studies together with the activation parameters obtained from the temperature dependence of reaction rate suggest that there is no involvement of any bridging group for electron transfer and the redox process may be taking place via outer sphere mechanism.
\end{abstract}

Keywords: Glutathione, Redox activity, Kinetics, Co(III) complex, Phenol-amide-amine coordination, NMR.

ᄂ _ - - - - - - - - - - - - - - - - - - - - - - - - - - - - - - - - - -

\section{INTRODUCTION}

Synthesis and isolation of multidentate carboxamido ligand containing $\mathrm{N}_{4} \mathrm{O}_{2}$ donor atoms in the form of amide, amine and phenolate groups have remained a long standing challenge [1-6] owing to their varied functionality during complexation. These ligands have proved to be excellent complexing agents for several metal ions such as $\mathrm{Mn}^{\mathrm{III/I}}[6], \mathrm{Fe}^{\mathrm{III/II}}$ [7-10], $\mathrm{Cr}^{\mathrm{III}}$ [11], $\mathrm{Co}^{\mathrm{III} / \mathrm{II}}$ [12-14] and $\mathrm{Cu}^{\mathrm{II}}$ [15], etc. It has been shown that the amide ligands have allowed the preparation of complexes with unusual geometries, oxidation and spin states $[16,17]$; and also these ligands improve the resistance of the complex to undergo an oxidative degradation [12-14], which makes them superior over other ligands. There has been a great surge of interest in the recent years on the study of the amide complexes of metal ions due to their ability to model active sites present in some metalloproteins [18-21].
In recent times, cobalt complexes are mainly in the focal point due to their role in biological domain [22] and also in the point of interest in experimental cancer therapy research because of their capacity to redox-dependent targeting the malignant tissue of solid tumors [23]. These complexes are also well suited for use as bio-reductive prodrugs, having a very inert oxidized cobalt(III) state and very labile reduced cobalt(II) state [24].

Of late, a series of substituted bis(thiosemicarbazone) cobalt(III) complexes were synthesized [25] and characterized by mass spectrometry, X-ray crystallography and multinuclear NMR spectroscopy. These compounds were proved to be potential anticancer agents in normoxic and hypoxic conditions [26] and believed to act as chaperones for the cytotoxic compounds [27].

Glutathione reduced (GSH), a biological reducing agent in thiol dependent enzymatic reactions has recently been

This is an open access journal, and articles are distributed under the terms of the Attribution 4.0 International (CC BY 4.0) License. This license lets others distribute, remix, tweak, and build upon your work, even commercially, as long as they credit the author for the original creation. You must give appropriate credit, provide a link to the license, and indicate if changes were made. 
reported to have anticancer activity [28] analogous to the $\mathrm{Co}$ (III) macrocyclic complexes. Novi [29] administered GSH to rats bearing aflatoxin B1 liver tumors and observed falling off of tumor growth leading to extended survival of the animals. Further, it is believed that as GSH is fairly abundant in cells throughout the body, the latter is instrumental in delayed reoxidation of $\mathrm{Co}$ (III) drugs resulting in hyper activation of same in hypoxic tissues. Several such Co(III) drugs have been demonstrated to be reduced to $\mathrm{Co}$ (II) within the hypoxic tumor tissue [30]. As Co(II) complexes are more labile, the cytotoxic ligands may be released from the "metal chaperon" and exert their anticancer activity [31], thus inhibiting the proliferation of malignant tumor cells.

In continuation of our earlier work on the redox reaction of GSH and cobalt(III) complex of hexadentate phenol-amide ligand [32], we report herein the synthesis and characterization of a $\mathrm{Co}(\mathrm{III})$ complex, $\left[\mathrm{Co}^{\mathrm{III}}(\mathrm{HL})\left(\mathrm{H}_{2} \mathrm{O}\right)\right]$ with a pentadentate ligand 1,5-bis(2-hydroxybenzamido)-3-aza pentane $\left(\mathrm{H}_{3} \mathrm{~L}\right)$ and its redox activity with GSH. The objective behind this study is to explain the ligand substitution dynamics of $\left[\mathrm{Co}^{\mathrm{III}}(\mathrm{HL})\right]$ with $\mathrm{GSH}$, to distinguish the reactive species, characterize reaction products and to establish the rate law and construe a plausible mechanism. Further, since NMR is an ideal tool for studying amino acids properties, an attempt has been made to use the time dependent FT-NMR technique to establish the redox behaviour exhibited by the Co(III)/GSH redox couple in a chemically and magnetically discriminated proton environment.

\section{EXPERIMENTAL}

The pentadentate ligand, $\mathrm{H}_{3} \mathrm{~L}$ is synthesized by a known method as discussed in our earlier paper [4] and characterized by ${ }^{1} \mathrm{H}$ NMR and IR spectroscopic methods. Glutathione reduced, GSH of Sigma-Aldrich, $99 \%$ was used as received. All other chemicals used in this experiment were of AnalaR grade. The $\mathrm{NaClO}_{4}$ solution used for ionic strength adjustments was prepared using standardized solutions of $\mathrm{NaOH}$ and $\mathrm{HClO}_{4}$. The stock solution of $\mathrm{NaClO}_{4}$ was adjusted to $\mathrm{pH} 6.0$ and estimated for $\mathrm{Na}^{+}$by a combined ion exchange alkalimetric procedure using Dowex 50W X8 resin in $\mathrm{H}^{+}$form. All rate measurements were made at $1.0 \mathrm{~mol} \mathrm{dm}^{-3}$ ionic strength. The GSH solution was always prepared fresh just before starting the kinetic runs. The stock solution of complex was cosseted from light and stored at low temperature $\left(10^{\circ} \mathrm{C}\right)$ in a refrigerator.

The mass spectrometric measurements were done by a Varian Inc., USA; model 410-proster binary LC with IT PDA Detectors. Direct infusion mass with ESI and APCI negative and positive mode ionization, mass ranging from 50 to 2000 $m / e$. TG-DTA measurements of the sample was carried out by Perkin Elmer USAA model Diamond TG/DTA in the temperature range $30-900{ }^{\circ} \mathrm{C}$ with a heating rate $10{ }^{\circ} \mathrm{C} / \mathrm{min}$. The elemental analysis ( $\mathrm{C}, \mathrm{H}$ and $\mathrm{N}$ ) was carried out with a Thermo Finnigan, Italy, model Flash EA 1112 series elemental analyser. Proton NMR time dependent spectra was taken in AV400Bruker 400 MHz High Resolution Multinuclear FT-NMR spectrometer.

A LABINDIA double beam spectrophotometer with a pair of $10 \mathrm{~mm}$ matched Teflon stoppered quartz cells was used for kinetics measurements. The temperature of the cell compartment was maintained $\left( \pm 0.1^{\circ} \mathrm{C}\right)$ by an electronically controlled thermostatting device. The $\mathrm{pH}$ measurements were made using an Elico digital $\mathrm{pH}$ meter model LI 120 equipped with a glass$\mathrm{Ag} / \mathrm{AgCl}, \mathrm{Cl}^{-}\left(3 \mathrm{~mol} \mathrm{dm}^{-3} \mathrm{NaCl}\right)$ electrode, CL 51. NBS buffers of $\mathrm{pH} 4.01,6.86$ and 9.20 were used to check the performance of the $\mathrm{pH}$ meter.

Kinetic measurements: The rate measurements were made spectrophotometrically under pseudo-first-order conditions at $\lambda=390 \mathrm{~nm}$, where the cobalt(III) complex is the main absorbing species. The decrease in absorbance with time of the reaction mixture was monitored against the corresponding solvent blank for at least $3 \mathrm{~h}$.

Synthesis of complex, $\left[\mathbf{C o}^{\mathrm{III}}(\mathbf{H L}) \mathbf{H}_{2} \mathbf{O}\right]: 50 \%(\mathrm{v} / \mathrm{v}) \mathrm{EtOH}$ $+\mathrm{H}_{2} \mathrm{O}$ solution of ligand, $\mathrm{LH}_{3}$ (structure 1) $(3.4 \mathrm{~g}, 10 \mathrm{mmol})$ and $\mathrm{LiOH} \cdot \mathrm{H}_{2} \mathrm{O}(0.5 \mathrm{~g}, 21 \mathrm{mmol})$ were mixed in $1: 2$ proportion to make the deprotonation of phenolic $\mathrm{OH}$ groups. Then, the metal salt $\mathrm{CoCl}_{2} \cdot 6 \mathrm{H}_{2} \mathrm{O}(2.38 \mathrm{~g}, 10 \mathrm{mmol})$ in solution phase is added drop-wise to the ligand solution and was stirred to obtain a uniform solution. The solution was allowed to undergo aerial oxidation for $24 \mathrm{~h}$. It was filtered off and the green colour residue was collected and recrystallized from $50 \%(\mathrm{v} / \mathrm{v}) \mathrm{EtOH}$ $+\mathrm{H}_{2} \mathrm{O}$ solutions. Unfortunately, we did not get the crystal for the complex, but the yield was good i.e. $2.18 \mathrm{~g}(83 \%)$. Anal. calcd. for $\mathrm{C}_{18} \mathrm{H}_{21} \mathrm{~N}_{3} \mathrm{O}_{5} \mathrm{Co}(\%)$ : C, 51.67; H, 5.02; N, 10.05 . Found: C, 50.938; H, 5.4; N, 10.15. The complex (structure 2) is sparingly soluble in water but soluble in methanol.

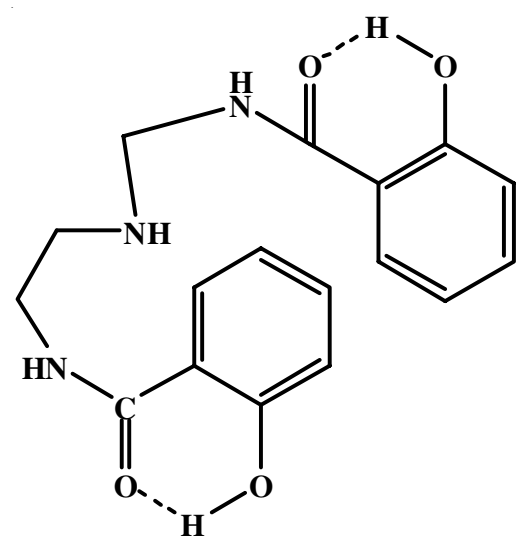

Structure 1: Structure of ligand $\left(\mathrm{LH}_{3}\right)$

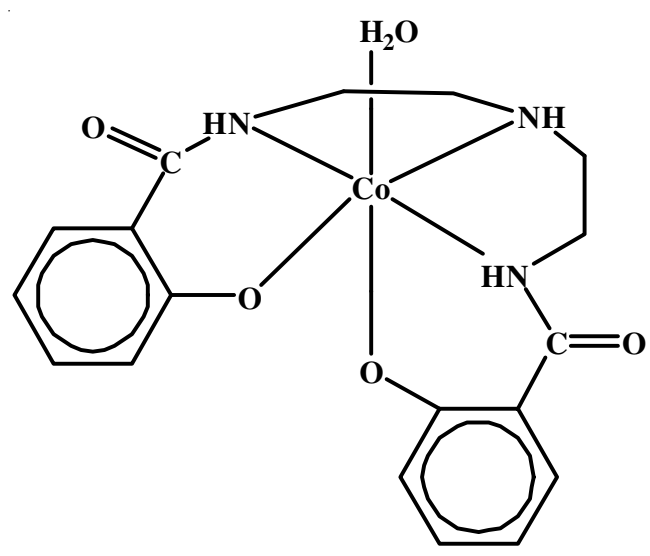

Structure 2: Structure of the complex $\left[\mathrm{Co}^{\mathrm{III}}(\mathrm{HL}) \mathrm{H}_{2} \mathrm{O}\right]$ 


\section{RESULTS AND DISCUSSION}

The synthesized $\left[\mathrm{Co}^{\mathrm{III}}(\mathrm{HL}) \mathrm{H}_{2} \mathrm{O}\right]$ is an octahedral cobalt complex of a pentadentate ligand coordinating through two phenolate, two amidate and one amine functional groups. The sixth site of this complex is occupied by a $\mathrm{H}_{2} \mathrm{O}$ molecule. This tentative structure (Scheme-I) is proposed by taking into account the following analytical evidences.

Thermal analysis (TG-DTA) of [ $\left.\mathrm{Co}^{\mathrm{III}}(\mathrm{HL})\right] \cdot \mathrm{H}_{2} \mathrm{O}$ : The TG curve of $\left[\mathrm{Co}^{\mathrm{III}}(\mathrm{HL})\left(\mathrm{H}_{2} \mathrm{O}\right)\right]$, (Fig. 1a) shows three successive degradation steps at $30-230,230-500,500-800{ }^{\circ} \mathrm{C}$. Initial weight loss of $11.59 \%$ in the temperature range $30-230{ }^{\circ} \mathrm{C}$ is attributed to two very close decomposition steps. The first $7 \%$ weight loss below $150{ }^{\circ} \mathrm{C}$ may be due to removal of lattice water. The next $4 \%$ weight loss is above $150^{\circ} \mathrm{C}$ indicating the removal of one coordinated water molecule from the complex. An observed weight loss of $50.177 \%$ and $13.058 \%$ in the $2^{\text {nd }}$ step and $3^{\text {rd }}$ step, respectively of the thermogram is concomitant to the metal coordinated ligand decomposition.

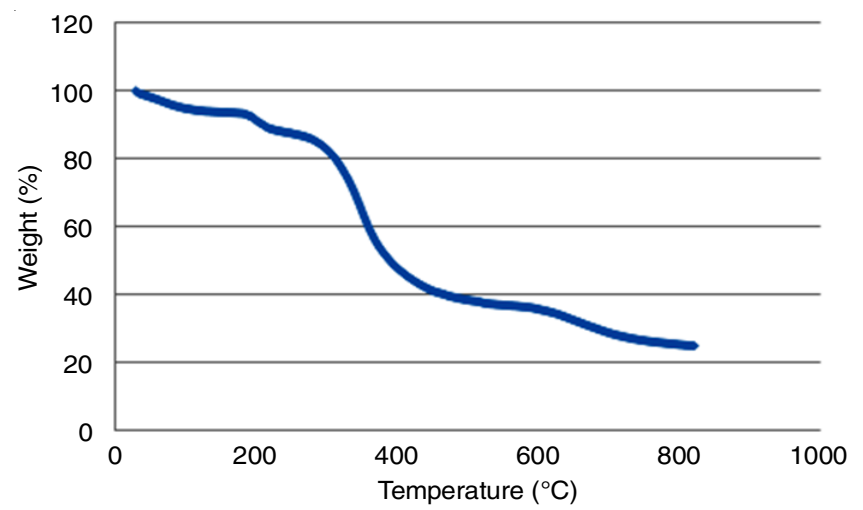

Fig. 1a. Thermogram of complex $\left[\mathrm{Co}^{\mathrm{III}}(\mathrm{HL})\left(\mathrm{H}_{2} \mathrm{O}\right)\right]$ at a heating rate $10{ }^{\circ} \mathrm{C} /$ min in the range 30 to $800{ }^{\circ} \mathrm{C}$

The ligand part of the complex is stable up to $240{ }^{\circ} \mathrm{C}$ and decomposes in two stages up to $800{ }^{\circ} \mathrm{C}$ leaving cobalt oxide and some carbon as residue. Ligand decomposition is fast in the first stages with a weight loss of $50.177 \%$ (calculated $49.52 \%$ ), assigned to the removal of non-coordinated hydrocarbon part of the ligand, while the actually coordinated part decomposes later in the second stage at $\sim 700{ }^{\circ} \mathrm{C}$. An exo-effect with the maximum centred at about $313^{\circ} \mathrm{C}$, associated with the decomposition of the complex connected with the ligand's oxidation, is apparent from the DTA curves shown in Fig. 1b. Similar observations are reported by Vanco et al. [33].

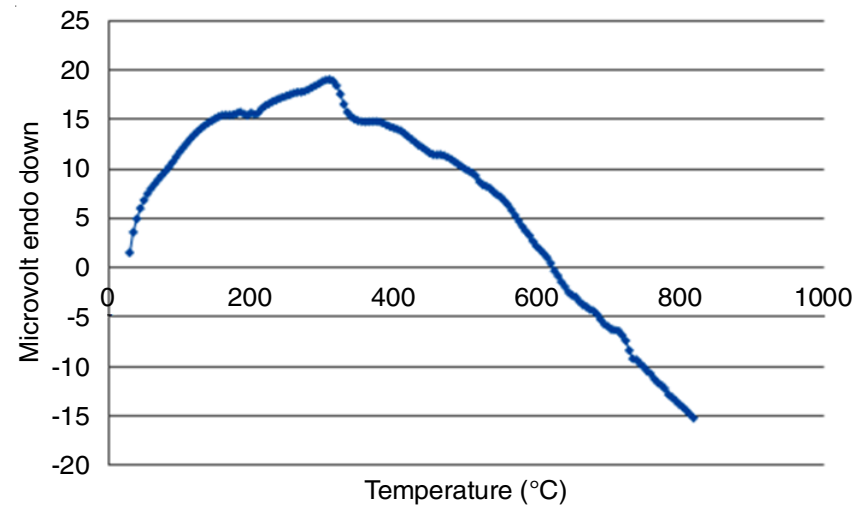

Fig. 1b. DTA curve of complex $\left[\mathrm{Co}^{\mathrm{III}}(\mathrm{HL})\left(\mathrm{H}_{2} \mathrm{O}\right)\right]$ at a heating rate $10{ }^{\circ} \mathrm{C} / \mathrm{min}$ in the range 30 to $900{ }^{\circ} \mathrm{C}$

Proton NMR: Proton NMR spectrum of [Co $\left.{ }^{\mathrm{III}}(\mathrm{HL})\left(\mathrm{H}_{2} \mathrm{O}\right)\right]$ is shown in Fig. 2. Coordination of amide-amine-phenolate moiety to $\mathrm{Co}$ (III) generates a set of three signals for aromatic proton in the 6.5-8.0 ppm range. The assignment of these aromatic proton signals reveals that $\mathrm{Ha}$ and $\mathrm{Hc}$ protons resonate at 7.70 and $7.40 \mathrm{ppm}$, respectively. These two aromatic proton signals are more deshielded as their position is ortho and para with respect to electron withdrawing carboxamide group and also meta to the electron donating phenolate group, whereas the $\mathrm{Hb}$ and $\mathrm{Hd}$ protons, ortho and para to phenolate group resonate at $6.89 \mathrm{ppm}$. The expected signals for aliphatic protons are observed as an overlapping signal in the range 3.2 to 3.7 ppm. The non-equivalent $\mathrm{CH}_{2}$ fragments protons ( $\mathrm{He}$ and $\mathrm{Hf}$ )

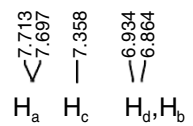

Aromatic protons

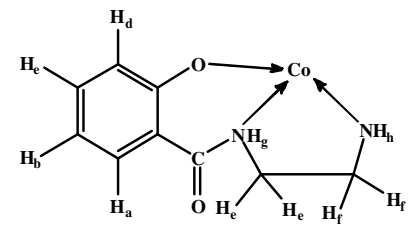

Aliphatic|protons

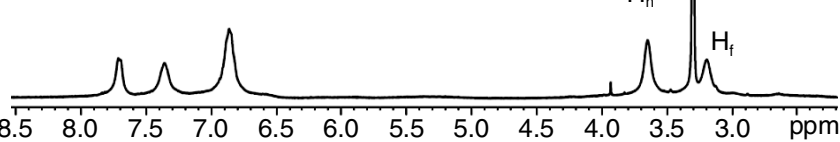

Fig. 2. ${ }^{1} \mathrm{H}$ NMR spectrum of $\left[\mathrm{Co}^{\mathrm{III}}(\mathrm{HL}) \mathrm{H}_{2} \mathrm{O}\right]$ in $50 \%(\mathrm{v} / \mathrm{v})$ deuterated methanol + water mixture<smiles>CC(NC(=O)CCC(N)C(=O)O)C(=O)NCC(=O)O</smiles><smiles>NC(CCC(=O)NC(C[Hg])C(=O)NCC(=O)O)C(=O)O</smiles>

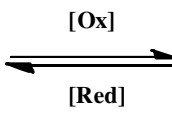

Scheme-I<smiles>NC(CCC(=O)NC(CSI)C(=O)NCC(=O)O)C(=O)O</smiles> 
give rise to multiplets at $\sim 3.2 \mathrm{ppm}$ because of their diastereotropic nature. The broad signal observed at around $3.65 \mathrm{ppm}$ is due to amine proton (Hh). Rest half of the ligand coordinated to $\mathrm{Co}$ (III) in the complex resonate at same frequencies as that of its symmetrical half, thus coalescing with the afore mentioned peaks.

ESI-Mass: The mass spectrum of the complex was scanned in the range: $100 \leq m / z \leq 2000$ (Fig. 3a and 3b) at collision energy $(\mathrm{CE}) \approx 3 \mathrm{eV}$. The base peak appear at $\mathrm{m} / \mathrm{z}$ 344.16 corresponds to protonated ligand $\left\{\mathrm{H}_{3} \mathrm{~L}+\mathrm{H}^{+}\right\}$(f.w. of $\mathrm{H}_{3} \mathrm{~L}$ : 343). The peak at $m / z 400$ is for $\mathrm{Co}(\mathrm{HL})$ complex (f.w. $59+341)$. Peak at $m / z 164$ is showing the fragment ion of ligand i.e. $\mathrm{C}_{6} \mathrm{H}_{4}(\mathrm{OH})(\mathrm{CONH}) \mathrm{CH}_{2} \mathrm{CH}_{2}$ having f.w. 164. The spectrum shows a low intense peak at $\mathrm{m} / \mathrm{z} 743$, which is attributed to $\left\{\mathrm{Co}+\mathrm{HL}+\mathrm{H}_{3} \mathrm{~L}\right\}$. The peaks observed at $\mathrm{m} / z, 562$ and 605 are attributed to $\left\{\mathrm{Co}(\mathrm{HL})+\mathrm{C}_{6} \mathrm{H}_{4}(\mathrm{O})(\mathrm{CONH}) \mathrm{CH}_{2} \mathrm{CH}_{2}\right\}$ and $\{\mathrm{Co}(\mathrm{HL})$ $\left.+\mathrm{C}_{6} \mathrm{H}_{4}(\mathrm{O})(\mathrm{CONH}) \mathrm{CH}_{2} \mathrm{CH}_{2} \mathrm{NHCH}_{2} \mathrm{CH}_{2}\right\}$ moieties, respectively. This fragmentation pattern followed by the complex is consistent with its structure.

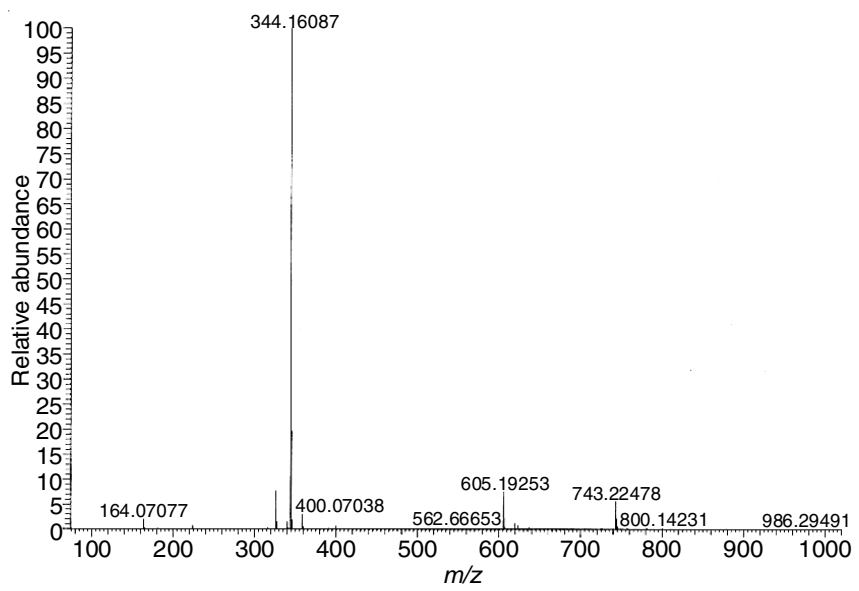

Fig. 3a. ESI-Mass spectrum of the $\left[\mathrm{Co}^{\mathrm{III}}(\mathrm{HL})\left(\mathrm{H}_{2} \mathrm{O}\right)\right]$

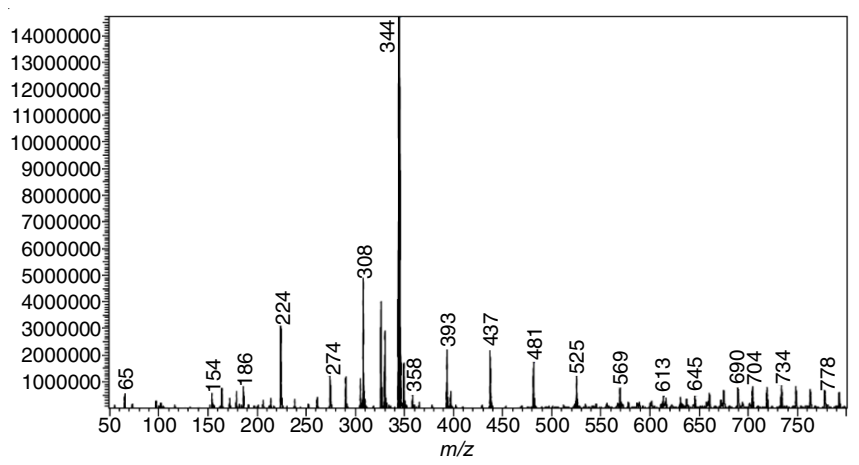

Fig. 3b. ESI-Mass spectrum of 1:4 ratio mixture of Co(III)HL and GSH

ESI-MS spectra: The ESI-MS spectra (Fig. 3b) recorded for the 1:4 ratio mixture of $\mathrm{Co}(\mathrm{III}) \mathrm{HL}$ and GSH gives intense peak at $m / z 308$ indicating the presence of unreacted GSH in protonated form. The appearance of peak at $\mathrm{m} / \mathrm{z}=613$. (obs.) against 612.57 (calc.) corresponds to the oxidized species GSSG. The observed peak at 481 corresponds to a $\mathrm{Co}^{\mathrm{II}}$ complex after fragmentation of the ligand $\left[\mathrm{Co}+(\mathrm{GSH})+\mathrm{C}_{6}(\mathrm{OH}) \mathrm{CN}\right.$ : $m / z=481.22]$. The most prominent peak at 344 is assigned to the mono-protonated ligand, $\mathrm{LH}_{4}{ }^{+}(\mathrm{m} / \mathrm{z}=344)$. Other peaks at $\mathrm{m} / \mathrm{z} 344,308$ etc. may be attributed to ligand peak and its fragment ions. The peak at 326 is also assigned to the ligand after its inequitable fragmentation $\left(\mathrm{LH}_{4}-\mathrm{OH}: m / z=326.39\right)$. Thus, the mass spectral data are consistent with reduction of the $\mathrm{Co}^{\text {III }}$ centre by GSH resulting in a $\mathrm{Co}^{\mathrm{II}}$ complex and subsequently dissociate under acidic conditions to the free ligand and its protonated form.

FT-IR spectra: $\left[\mathrm{Co}(\mathrm{HL})\left(\mathrm{H}_{2} \mathrm{O}\right)\right]$ displays bands at 1639 , 1541 and $1487 \mathrm{~cm}^{-1}$ due to $v_{\text {str }}(\mathrm{C}=\mathrm{O}), \mathrm{v}_{\mathrm{str}}(\mathrm{C}=\mathrm{N})$ of deprotonated amide and $v_{\text {str }}(C=C)$ of aromatic group, respectively. A strong band at $1639 \mathrm{~cm}^{-1}$ is characteristic of $v_{\text {str }}(C=O)$ of coordinated primary amide. $v_{\text {str }}(\mathrm{O}-\mathrm{H})$ of phenolic group and the same of coordinated water together coalesce with the $v_{\text {str }}(\mathrm{N}-\mathrm{H})$ of secamide to result in a broad peak observed at $3442.04 \mathrm{~cm}^{-1}$. The weak band at $2377 \mathrm{~cm}^{-1}$ together with $2317 \mathrm{~cm}^{-1}$ are attributed to intra-molecular $\mathrm{H}$-bonds of ligated water molecules and band at 1541 , partially overlapped with $\mathrm{v}_{\text {str }}(\mathrm{C}=\mathrm{O})$ of $(\mathrm{O}=\mathrm{C}$ $\mathrm{NH}_{2}$ ) owing to the bending mode of water molecules [34]. The bands at $1346 \mathrm{~cm}^{-1}(\mathrm{w})$ and $1305 \mathrm{~cm}^{-1}$ are ascribed to the $\mathrm{O}-\mathrm{H}$ bending and $\mathrm{v}_{\mathrm{str}}(\mathrm{C}=\mathrm{O})$ of co-ordinated phenolic groups and those at 833 and $750 \mathrm{~cm}^{-1}$ are assigned to the $(1,2) \mathrm{di}-$ substituted aromatic moiety. The bands at 1091, 1026, 914 $\mathrm{cm}^{-1}\left(\mathrm{CH}_{2}\right.$ - rocking) and prominent peaks at 1487 and 1383 $\mathrm{cm}^{-1}$ due to $\mathrm{CH}_{2}$ deformation vibration are concomitant with the unsymmetrical array of diene spacer unit [32].

UV-visible spectra: The electronic spectra of Co(III) complex (Fig. 4) show two absorption bands each observed at 24,813 and $33,783 \mathrm{~cm}^{-1}$ correspond to two transitions ${ }^{1} \mathrm{~A}_{1 \mathrm{~g}} \rightarrow$ ${ }^{3} \mathrm{~T}_{1 \mathrm{~g}}(\mathrm{~F})\left(\mathrm{V}_{1}\right)$ and ${ }^{1} \mathrm{~A}_{1 \mathrm{~g}}(\mathrm{~F}) \rightarrow{ }^{1} \mathrm{~T}_{2 \mathrm{~g}}(\mathrm{P})\left(\mathrm{V}_{2}\right)$, respectively. The ratio of these two energies, $\left\{v_{2} / v_{1}\right\}=1.36$, can be fitted to the modified Tanabe-Sugano diagram [35] and the corresponding Dq/ $B$ value of 39 is obtained. The value of $E / B^{\prime}$ for the lowest energy transition can be read from the diagram as 37 which lead to $\mathrm{B}^{\prime}$ value of $670 \mathrm{~cm}^{-1}$.

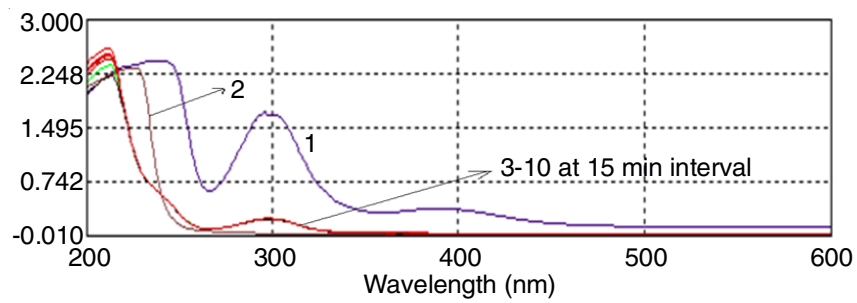

Fig. 4. Repetitive UV-visible spectral scan of the mixture of $\left[\mathrm{Co}^{\text {III }}(\mathrm{HL})\left(\mathrm{H}_{2} \mathrm{O}\right)\right]$ and GSH. [Complex] $=2.5 \times 10^{-4} \mathrm{M}(1) ;[\mathrm{GSH}]=2.5 \times 10^{-3} \mathrm{M}(2)$ and mixture after $30 \mathrm{~s}$ of mixing (3) (3-10) at $15 \mathrm{~min}$ interval of time, at $\mathrm{I}=1.0 \mathrm{M}\left(\mathrm{NaClO}_{4}\right) ; \mathrm{pH} \approx 5.70$ and temp. $25^{\circ} \mathrm{C}$

The apparent value of $\mathrm{B}^{\prime}$ in the complex is much smaller than $\mathrm{Co}^{3+}$ ion $\left(1100 \mathrm{~cm}^{-1}\right)$ [36] is obviously due to the nephelauxtic effect and is attributed to delocalization of the metal electrons over molecular orbitals that encompass both the metal and the ligand.

\section{$\mathrm{Co}^{\text {III }}(\mathrm{L}) \mathrm{H}_{2} \mathrm{O}-\mathrm{GSH}$ interaction study}

UV-visible study: The Co(III) complex was mixed with GSH in a 1:2 proportion and kept overnight at room temperature. $\mathrm{Co}(\mathrm{II})$ at the end of the reaction was estimated spectrophotometrically following the method of Kitson [37]. To the given amount of reaction mixture, $\mathrm{HClO}_{4}, \mathrm{NH}_{4} \mathrm{NCS}(50 \%)$ and $\mathrm{CH}_{3} \mathrm{COCH}_{3}$ were added. The absorbance of the deep blue 
solution due to the formation of $\mathrm{Co}(\mathrm{CNS})_{4}{ }^{2-}$ was measured at $625 \mathrm{~nm}\left(\varepsilon_{\max }=1023 \mathrm{~mol} \mathrm{~L}^{-1} \mathrm{~cm}^{-1}\right)$. Concentration of $\mathrm{Co}$ (II) was estimated by comparing with a calibration curve constructed with standard $\mathrm{Co}(\mathrm{II})$ solution under identical conditions.

${ }^{1} \mathbf{H}$ NMR study: $\mathrm{Co}^{\mathrm{III}}(\mathrm{HL}) \mathrm{H}_{2} \mathrm{O}$ is an octahedral cobalt complex of a pentadentate ligand, $\mathrm{H}_{3} \mathrm{~L}$. The sixth site of this complex is occupied by a $\mathrm{H}_{2} \mathrm{O}$ molecule. In the other hand, GSH is a tripeptide consisting of glutamic acid, cysteine and glycine amino acids. It has several potential binding sites, i.e. glutamyl (Glu) amino and carboxylate groups, glycinyl (Gly) carboxylate, cysteine (Cys) thiol group and two amide groups. The structure of glutathione is such that all its potential binding sites cannot be simultaneously coordinated to the same metal ion. Among these, thiol-S atom is the more prominating binding side as it is a good donor atom.

The interaction between $\mathrm{Co}^{\mathrm{III}}(\mathrm{HL}) \mathrm{H}_{2} \mathrm{O}$ and GSH was studied by ${ }^{1} \mathrm{H}$ NMR spectroscopy taking repetitive scan at different intervals of time. Free GSH has six characteristic protons that show NMR peak at chemical shift (a) 2.19-Glu $\mathrm{CH}_{2} \beta$, (b)

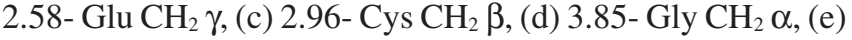
4.0- Glu CH $\alpha$ and (f) 4.59-Cys $\mathrm{CH} \alpha$ ppm [38]. The proton NMR of GSH in presence of $\mathrm{Co}$ (III) complex at different time interval from $1 \mathrm{~min}$ to $2 \mathrm{~h}$ are superposed and shown in Fig. 5 and the expanded spectrum taken at $1 \mathrm{~min}$ and $2 \mathrm{~h}$ after mixing are shown in Fig. 5a and 5b, respectively. Changes observed in the spectrum during the period of scanning are the initial disappearance of the fine structure and subsequent broadening of the signals of GSH. Reaction of GSH with Co(III)HL complex led to the appearance of new peaks at 3.33 and $3.38 \mathrm{ppm}$ (Cys$\mathrm{CH}_{2} \beta$ ) (Fig. 5a), while the same resonate at 2.93 and $2.98 \mathrm{ppm}$ for free GSH. This corresponds to formation of the oxidized form of glutathione, GSSG $[38,39]$. The complex $\mathrm{Co}^{\mathrm{III}}(\mathrm{HL}) \mathrm{H}_{2} \mathrm{O}$ also resonates at around $3.30 \mathrm{ppm}$ and due to this, there is some overlapping of its peak with the doublet of GSSG at 3.33 and $3.38 \mathrm{ppm}$.

Another important change to be considered in the spectrum is the reduction in the intensities and/or areas of peaks of free GSH with time interval from $1 \mathrm{~min}$ to $2 \mathrm{~h}$. This observation is obviously due to decrease in the concentration of free GSH during its reaction with complex. A slow but steady

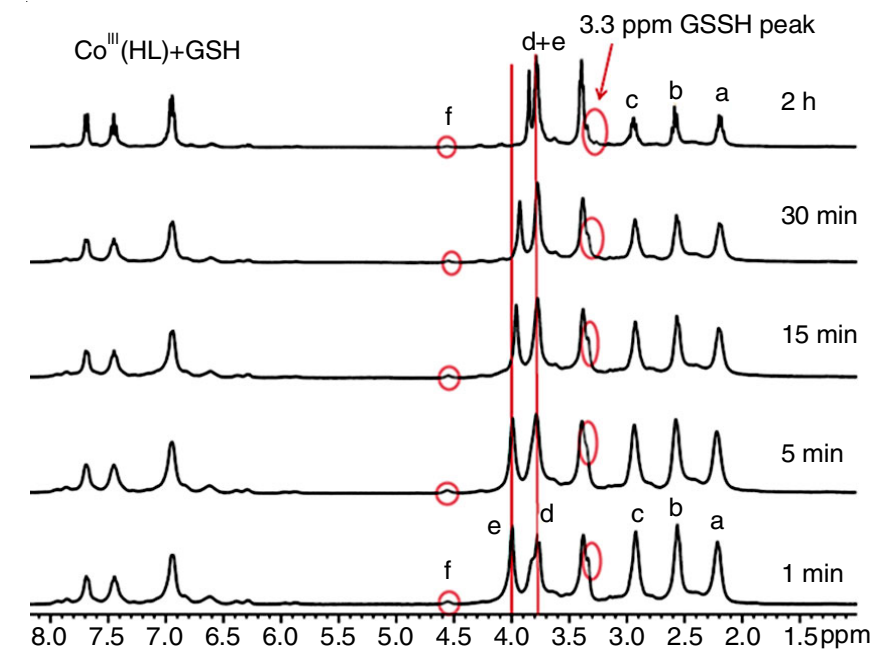

Fig. 5. Repetitive ${ }^{1} \mathrm{H}$ NMR scan of 1:6 molar ratio mixture of $\left[\mathrm{Co}^{\mathrm{III}}(\mathrm{HL})\left(\mathrm{H}_{2} \mathrm{O}\right)\right]$ and GSH solution after $1 \mathrm{~m}, 5 \mathrm{~m}, 15 \mathrm{~m}, 30 \mathrm{~m}$ and $2 \mathrm{~h}$ of mixing disappearance of Cys- $\mathrm{CH} \alpha$ proton peak intensity at $\sim 4.5 \mathrm{ppm}$ with simultaneous appearance of new peaks at 4.3 and 4.1 ppm, respectively, also supports the conversion of GSH to GSSG. The upfield shifting of the peak at $4.0 \mathrm{ppm}$ towards the $3.77 \mathrm{ppm}$ peak and finally merging with each other supports the transformation of GSH to GSSG. This transformation followed by merger of the peaks is a consequence of dimerization and associated conformational changes that brings about the chemical shift of Gly- $\mathrm{CH}_{2}$ (a proton) and Glu-CH(f proton) to converge and settle at $3.77 \mathrm{ppm}$. The relatively fast transformation of GSH to GSSG as evident from both electronic spectra and NMR studies suggest that there is no involvement of any bridging group for electron transfer and hence the redox process may be taking place via outer sphere mechanism.

The observed shift of peak position of cysteine protons i.e. Cys- $\mathrm{CH} \alpha$ peak from $4.5 \rightarrow 4.3 \mathrm{ppm}$ and $\mathrm{Cys}_{-} \mathrm{CH}_{2} \beta$ peak from $2.98 \rightarrow 3.33 \mathrm{ppm}$ is consistent with direct thiolate ligation to the cobalt centre and after binding of GSH through $\mathrm{S}$ atom the cysteine protons are conformationally adjacent to the cobalt ion appeared to be strongly affected [40,41]. Similar observation also reported by Sun et al. [42] in their study of interaction of $\mathrm{Sb}$ (III)tartarate with glutathione. As expected, during the reaction, $\mathrm{Co}$ (III) complex was reduced by GSH to form a $\mathrm{Co}(\mathrm{II})$ complex and a substantial amount of the total GSH was oxidized to form GSSG as judged by ${ }^{1} \mathrm{H}$ NMR spectroscopy. This transformation was further evidenced by the electronic spectroscopy discussed earlier.

Kinetics of redox reaction: Oxidation of GSH leads to formation of dimer GSSG [21].

$$
2 \mathrm{GSH} \longrightarrow \mathrm{GSSG}+2 \mathrm{H}^{+}+2 \mathrm{e}^{-}
$$

Estimation of unreacted GSH in the mixture suggested that 2 mol of GSH consumed 2 mol of complex, $\left[\mathrm{Co}^{\mathrm{III}}(\mathrm{HL})\left(\mathrm{H}_{2} \mathrm{O}\right)\right]^{3+}$ such that

$$
\begin{aligned}
& 2\left[\mathrm{Co}^{\mathrm{III}}(\mathrm{HL})\left(\mathrm{H}_{2} \mathrm{O}\right)\right]^{3+}+2 \mathrm{GSH} \longrightarrow \\
& 2\left[\mathrm{Co}^{\mathrm{II}}(\mathrm{HL})\left(\mathrm{H}_{2} \mathrm{O}\right)\right]^{2+}+2 \mathrm{GSSG}
\end{aligned}
$$

The rate of the reaction is given by

$$
\text { Rate }=\mathrm{k}[\mathrm{GSH}]^{a}[\text { complex }]^{\mathrm{b}}
$$

where $\mathrm{k}$ is the rate constant and $\mathrm{a}, \mathrm{b}$ are the order of the reaction with respect to the concentrations of GSH and complex, respectively. It was found that the rate is dependent on the first power of both oxidant and the complex, i.e. $\mathrm{a} \approx \mathrm{b}=1$, in agreement with previous study [43].

Since Co(III) complexes are all one-electron oxidants, the oxidation of GSH would give the radical intermediate and the following mechanism is proposed.

$$
\begin{gathered}
\mathrm{GSH} \rightleftharpoons \mathrm{GS}^{-}+\mathrm{H}^{+} \\
\mathrm{GS}^{-} \longrightarrow \mathrm{GS}^{\bullet}+\mathrm{e}^{-} \\
2 \mathrm{GS} \longrightarrow \mathrm{GSSG}
\end{gathered}
$$

where the second step is the rate determining step. Under pseudo-first order conditions, in which [GSH] >> [complex], the concentration of GSH is practically constant throughout the reaction.

For a first order dependence of reaction on [complex], the observed absorbance time data pairs were fit to the equation:

$$
A_{t}=\left(A_{o}-A_{\infty}\right) \exp \left(-k_{\text {obs }} t\right)+A_{\infty}
$$


where, $\mathrm{A}_{\circ}, \mathrm{A}_{\mathrm{t}}$ and $\mathrm{A}_{\infty}$ are the initial absorbance of the complex, absorbance of reaction mixture at time " $t$ " and final absorbance of the reaction mixture (at time, $\mathrm{t}=\infty$ ), respectively.

Therefore, the reaction rate is given by

$$
\text { Rate } \approx-\mathrm{d}[\text { complex }] / \mathrm{dt}=\mathrm{k}_{\mathrm{obs}}[\text { complex }]
$$

where, $\mathrm{k}_{\mathrm{obs}}$ is the observed rate of the reaction, given by

$$
\mathrm{k}_{\mathrm{obs}}=\mathrm{k}_{0}^{\text {red }}+\mathrm{k}_{1}{ }^{\text {red }}[\mathrm{GSH}]_{\mathrm{T}}
$$

The rate data in Table-1 have been fitted to eqn. 7. It is observed that $\mathrm{k}_{0}^{\text {red }}$ is statistically insignificant, indicating absence of formation of precursor complex. Outer sphere association complex formation is also not evident from the UV-

\begin{tabular}{|c|c|c|c|c|c|}
\hline \multicolumn{6}{|c|}{$\begin{array}{c}\text { TABLE-1 } \\
\text { RATE DATA FOR THE REDUC }\end{array}$} \\
\hline $\begin{array}{c}{\left[\mathrm{HClO}_{4}\right]} \\
(\mathrm{mol} \\
\left.\mathrm{dm}^{-3}\right)\end{array}$ & $\begin{array}{c}{[\mathrm{GSH}]} \\
(\mathrm{mol} \\
\left.\mathrm{dm}^{-3}\right)\end{array}$ & $\begin{array}{c}10^{4} \mathrm{k}_{\text {obs }} \\
\left(\mathrm{s}^{-1}\right) \\
\left(25.0^{\circ} \pm\right. \\
\left.0.1^{\circ} \mathrm{C}\right) \\
\end{array}$ & $\begin{array}{c}10^{4} \mathrm{k}_{\text {obs }} \\
\left(\mathrm{s}^{-1}\right) \\
\left(35.0^{\circ} \pm\right. \\
\left.0.1^{\circ} \mathrm{C}\right) \\
\end{array}$ & $\begin{array}{c}10^{4} \mathrm{k}_{\mathrm{obs}} \\
\left(\mathrm{s}^{-1}\right) \\
(40.0 \pm \\
\left.0.1^{\circ} \mathrm{C}\right) \\
\end{array}$ & $\begin{array}{c}10^{4} \mathrm{k}_{\text {obs }} \\
\left(\mathrm{s}^{-1}\right) \\
\left(45.0^{\circ} \pm\right. \\
\left.0.1^{\circ} \mathrm{C}\right) \\
\end{array}$ \\
\hline 0.025 & 0.005 & 0.16 & 0.22 & 0.33 & 0.55 \\
\hline 0.025 & 0.010 & 0.35 & 0.48 & 0.74 & 1.20 \\
\hline 0.025 & 0.015 & 0.61 & 0.82 & 1.26 & 2.06 \\
\hline 0.025 & 0.020 & 0.72 & 0.98 & 1.50 & 2.45 \\
\hline 0.025 & 0.025 & 0.86 & 1.16 & 1.79 & 2.92 \\
\hline 0.050 & 0.005 & 0.21 & 0.28 & 0.43 & 0.69 \\
\hline 0.050 & 0.010 & 0.39 & 0.52 & 0.81 & 1.32 \\
\hline 0.050 & 0.015 & 0.57 & 0.76 & 1.17 & 1.91 \\
\hline 0.050 & 0.020 & 0.70 & 0.94 & 1.45 & 2.36 \\
\hline 0.050 & 0.025 & 0.83 & 1.12 & 1.73 & 2.82 \\
\hline 0.100 & 0.005 & 0.18 & 0.24 & 0.37 & 0.61 \\
\hline 0.100 & 0.010 & 0.38 & 0.51 & 0.79 & 1.29 \\
\hline 0.100 & 0.015 & 0.53 & 0.72 & 1.10 & 1.80 \\
\hline 0.100 & 0.020 & 0.67 & 0.91 & 1.40 & 2.29 \\
\hline 0.100 & 0.025 & 0.82 & 1.11 & 1.71 & 2.79 \\
\hline 0.200 & 0.005 & 0.14 & 0.19 & 0.29 & 0.47 \\
\hline 0.200 & 0.010 & 0.33 & 0.44 & 0.68 & 1.11 \\
\hline 0.200 & 0.015 & 0.56 & 0.76 & 1.16 & 1.90 \\
\hline 0.200 & 0.020 & 0.64 & 0.87 & 1.34 & 2.18 \\
\hline 0.200 & 0.025 & 0.79 & 1.07 & 1.64 & 2.68 \\
\hline
\end{tabular}
visible spectrum, due to non-appearance of any new band.

Similar linear dependence of $\mathrm{k}_{\mathrm{obs}}$ on [GSH] has also been reported by Jovanovic et al. [44] for the reduction in some neutral $\mathrm{Pt}(\mathrm{IV})$ complexes $\left[\mathrm{Pt}^{\mathrm{IV}} \mathrm{Cl}_{4}(\mathrm{~N}-\mathrm{N})\right]$ by glutathione. The activation parameters $\left(\Delta \mathrm{H}^{\#}=44.03 \pm 8.9 \mathrm{~kJ} \mathrm{~mol}^{-1}, \Delta \mathrm{S}^{\#}=-145.6\right.$ $\pm 13.8 \mathrm{~J} \mathrm{~K}^{-1} \mathrm{~mol}^{-1}$ (Table-2) were calculated from the temperature dependence of $\mathrm{k}_{1}$ red.

It is observed that the moderate negative value of $\Delta \mathrm{S}^{\#}$ is

\begin{tabular}{|c|c|c|}
\hline \multicolumn{3}{|c|}{$\begin{array}{c}\text { TABLE-2 } \\
\text { CALCULATED VALUES OF RATE } \\
\text { CONSTANT AND ACTIVATION PARAMETERS }\end{array}$} \\
\hline Temp. $\left({ }^{\circ} \mathrm{C}\right)$ & $10^{5} \mathrm{k}_{0}^{\text {red }}\left(\mathrm{s}^{-1}\right)$ & $10^{4} \mathrm{k}_{1}^{\text {red }}\left(\mathrm{dm}^{3} \mathrm{~mol}^{-1} \mathrm{~s}^{-1}\right)$ \\
\hline 25.0 & 0.321 & 32.67 \\
\hline 35.0 & 0.424 & 44.20 \\
\hline 40.0 & 0.668 & 67.78 \\
\hline 45.0 & 1.081 & 110.79 \\
\hline${ }^{\$} \Delta \mathrm{H}^{\#}\left(\mathrm{~kJ} \mathrm{~mol}^{-1}\right)$ & - & $44.03 \pm 8.9$ \\
\hline${ }^{\$} \Delta \mathrm{S}^{\#}\left(\mathrm{~J} \mathrm{~K}^{-1} \mathrm{~mol}^{-1}\right)$ & - & $-145.6 \pm 13.8$ \\
\hline
\end{tabular}
associated with a low positive value of $\Delta \mathrm{H}^{\#}$ for this reaction.
This enunciates the fact that the electron transfer between the substrate and the reductant does not necessarily involve formation of any precursor complex to proceed via an inner sphere mechanism. The structure of the complex is such that its "close" or crowded octahedral geometry around the metal ion prohibits change in the coordination sphere for the formation of precursor associative complex, compelling the electron transfer process to proceed through an outer sphere mechanism [45].

\section{Conclusion}

An octahedral cobalt complex of a pentadentate ligand coordinating through two phenolate, two amidate and one amine functional groups is synthesized and characterized by different analytical, thermal and spectrometric techniques. Redox reaction of the complex with tripeptide glutathione (GSH) was studied as a function of time both by conventional UVvisible and NMR technique. The time dependent FT-NMR study reveals that the peaks of free GSH disappear and new peaks of GSSG start appear supporting the fact that the former undergoes oxidative dimerization to result the latter. Rate of dimerization of GSH is found to be rapid and hence an outersphere electron transfer within the $\mathrm{Co}$ III/GSH redox couple may be predicted. The activation parameters obtained from the temperature dependence of reaction rates further corroborates the outer sphere mode of electron transfer as evidenced by the NMR technique.

\section{ACKNOWLEDGEMENTS}

One of the authors (AR), Research Scholar in Department of Chemistry, FST, IFHE is thankful to the University for necessary financial support.

\section{CONFLICT OF INTEREST}

The authors declare that there is no conflict of interests regarding the publication of this article.

\section{REFERENCES}

1. C.A. Jiménez, J.B. Belmar, J.Alderete, F.S. Delgado, M. López-Rodríguez, O. Peña, M. Julve and C. Ruiz-Perez, Dalton Trans., 2135 (2007); https://doi.org/10.1039/B617604F.

2. E. Toyota and Y. Yamamoto, Bull. Chem. Soc. Jpn., 64, 3627 (1991); https://doi.org/10.1246/bcsj.64.3627.

3. S. Nayak, A.C. Dash and G.K. Lahiri, Transition Met. Chem., 33, 39 (2008); https://doi.org/10.1007/s11243-007-9012-4.

4. S. Nayak, A.C. Dash, P.K. Nayak and D. Das, Transition Met. Chem., 30, 917 (2005); https://doi.org/10.1007/s11243-005-5627-5.

5. S. Nayak, G.S. Brahma, K.V. Reddy, K.V. Reddy and A.C. Dash, Polyhedron, 30, 1637 (2011); https://doi.org/10.1016/j.poly.2011.03.032.

6. S.K. Chandra and A. Chakravorty, Inorg. Chem., 31, 760 (1992); https://doi.org/10.1021/ic00031a013.

7. D.S. Marlin and P.K. Mascharak, Chem. Soc. Rev., 29, 69 (2000); https://doi.org/10.1039/a905282h.

8. K.L. Kostka, B.G. Fox, M.P. Hendrich, T.J. Collins, C.E.F. Rickard, L.J. Wright and E. Munck, J. Am. Chem. Soc., 115, 6746 (1993); https://doi.org/10.1021/ja00068a035.

9. J.M. Domínguez-Vera, J. Suárez-Varela, I. Ben Maimoun and E. Colacio, Eur. J. Inorg. Chem., 2005, 1907 (2005); https://doi.org/10.1002/ejic.200400911.

10. A.K. Singh and R. Mukherjee, Inorg. Chem., 44, 5813 (2005); https://doi.org/10.1021/ic050057s. 
11. T.J. Collins, B.D. Santarsiero and G.H. Spies, J. Chem. Soc. Chem. Commun., 681 (1983); https://doi.org/10.1039/c39830000681.

12. T.J. Collins, T.G. Richmond, B.D. Santarsiero and B.G.R.T. Treco, J. Am. Chem. Soc., 108, 2088 (1986); https://doi.org/10.1021/ja00268a058.

13. T.J. Collins, Acc. Chem. Res., 27, 279 (1994); https://doi.org/10.1021/ar00045a004.

14. O. Rotthaus, S. LeRoy, A. Tomas, K.M. Barkigia and I. Artaud, Eur. J. Inorg. Chem., 2004, 1545 (2004); https://doi.org/10.1002/ejic.200300645.

15. T. Kiss, K. Petrohán, P. Buglyó, D. Sanna, G. Micera, J. Costa Pessoa and C. Madeira, Inorg. Chem., 37, 6389 (1998); https://doi.org/10.1021/ic9802202.

16. F.C. Anson, T.J. Collins, T.G. Richmond, B.D. Santarsiero, J.E. Toth and B.G.R.T. Treco, J. Am. Chem. Soc., 109, 2974 (1987); https://doi.org/10.1021/ja00244a020.

17. T.J. Collins and S.W. Gordon-Wylie, J. Am. Chem. Soc., 111, 4511 (1989); https://doi.org/10.1021/ja00194a063.

18. D.H. Petering, R.W. Byrnes and W.E. Antholine, Chem. Biol. Interact., 73, 133 (1990): https://doi.org/10.1016/0009-2797(90)90001-4.

19. J. Stubbe and J.W. Kozarich, Chem. Rev., 87, 1107 (1987); https://doi.org/10.1021/cr00081a011.

20. S.M. Hecht, Acc. Chem. Res., 19, 383 (1986); https://doi.org/10.1021/ar00132a002.

21. Y. Sigura, T. Takita and H. Umezawa, Met. Ions Biol. Syst., 19, 81 (1985).

22. M.C. Heffern, V. Reichova, J.L. Coomes, A.S. Harney, E.A. Bajema and T.J. Meade, Inorg. Chem, 54, 9066 (2015); https://doi.org/10.1021/acs.inorgchem.5b01415.

23. U. Jungwirth, C.R. Kowol, B.K. Keppler, C.G. Hartinger, W. Berger and P. Heffeter, Antioxid. Redox Signal., 15, 1085 (2011); https://doi.org/10.1089/ars.2010.3663.

24. M.D. Hall, T.W. Failes, N. Yamamoto and T.W. Hambley, Dalton Trans., 3983 (2007); https://doi.org/10.1039/b707121c.

25. A.P. King, H.A. Gellineau, J.-E. Ahn, S.N. MacMillan and J.J. Wilson, Inorg. Chem., 56, 6609 (2017); https://doi.org/10.1021/acs.inorgchem.7b00710.

26. I.C.A. de Souza, L.V. Faro, C.B. Pinheiro, D.T.G. Gonzaga, F. de Carvalho da Silva, V.F. Ferreira, F. da Silva Miranda, M. Scarpellini and M. Lanznaster, Dalton Trans., 45, 13671 (2016); https://doi.org/10.1039/C6DT02456D.
27. N. Yamamoto, A.K. Renfrew, B.J. Kim, N.S. Bryce and T.W. Hambley, J. Med. Chem., 55, 11013 (2012); https://doi.org/10.1021/jm3014713.

28. K. Zhang, P. Mack and K.P. Wong, Int J. Oncol., 12, 871 (1998); Chem. Abstr., 128, 45163 (1998).

29. A.M. Novi, Science, 212, 541 (1981); https://doi.org/10.1126/science.6782675.

30. W.A. Denny, Eur. J. Med. Chem., 36, 577 (2001); https://doi.org/10.1016/S0223-5234(01)01253-3.

31. A.K. Renfrew, N.S. Bryce and T.W. Hambley, Chem. Sci., 4, 3731 (2013); https://doi.org/10.1039/c3sc51530c

32. S. Nayak, K.V. Reddy and A.C. Dash, Transition Met. Chem., 39, 177 (2014); https://doi.org/10.1007/s11243-013-9787-4.

33. J. Vanèo, Z. Trávníèek, O. Kozák and R. Boèa, Int. J. Mol. Sci., 16, 9520 (2015); https://doi.org/10.3390/ijms16059520.

34. T.P. Amaladhas and S.S. Thavamani, Adv. Mater. Lett., 4, 213 (2013); https://doi.org/10.5185/amlett.2012.7380.

35. Y. Tanabe and S.J. Sugano, J. Phys. Soc. Jpn., 9, 753 (1954); https://doi.org/10.1143/JPSJ.9.753.

36. A.B.P. Lever, Inorganic Electronic Spectroscopy, Elsevier: Amsterdam, p. 115 (1986).

37. R.E. Kitson, Anal. Chem., 22, 664 (1950); https://doi.org/10.1021/ac60041a012.

38. L.E.H. Paul, B. Therrien and J. Furrer, Inorg. Chem., 51, 1057 (2012); https://doi.org/10.1021/ic2021935.

39. F. Giannini, G. Suss-Fink and J. Furrer, Inorg. Chem., 50, 10552 (2011); https://doi.org/10.1021/ic201941j.

40. K.L. Brown, X. Zou, S.R. Savon and D.W. Jacobsen, Biochemistry, 32, 8421 (1993); https://doi.org/10.1021/bi00084a006.

41. S.M. Polson, L. Hansen and G.L. Marzilli, Inorg. Chem., 36, 307 (1997); https://doi.org/10.1021/ic961019z.

42. H. Sun, S.C. Yan and W.S. Cheng, Eur. J. Biochem., 267, 5450 (2000); https://doi.org/10.1046/j.1432-1327.2000.01605.x.

43. H.M. Abdel-Halim and Y. Al-Lawatia, Asian J. Chem., 6, 655 (1994).

44. S. Jovanovic, B. Petrovic, Z.D. Bugarcic and R. Van Eldik, Dalton Trans., 42, 8890 (2013); https://doi.org/10.1039/c3dt50751c.

45. D.F. Shriver and P.W. Atkins, Inorganic Chemistry, Oxford University Press: Oxford (2009). 